\title{
New Records of Social Wasps (Hymenoptera: Vespidae: Polistinae) in Amazonas State, Brazil
}

\author{
Alexandre Somavilla ${ }^{\bowtie}$ Marcio Luiz de Oliveira
}

Instituto Nacional de Pesquisas da Amazônia, e-mail: alexandre.s@hotmail.com (Autor para correspondência ${ }^{\bowtie}$ ), mlolivei@inpa.gov.br.

EntomoBrasilis 6(2): 157-159 (2013)

\begin{abstract}
In this paper we record the occurrence of Clypearia apicipennis (Spinola, 1851), Leipomeles pusilla (Ducke, 1904), Metapolybia nigra Richards, 1978, Parachartergus richardsi Willink, 1951 and Pseudopolybia langi Bequaert, 1944 in Amazonas State for the first time, including distribution notes.
\end{abstract}

Keywords: Biogeography; Distribution; Jaú National Park; Ducke Reserve.

\section{Novos Registros de Vespas Sociais (Hymenoptera: Vespidae: Polistinae) no Estado do Amazonas, Brasil}

Resumo. Nesse trabalho registramos a ocorrência de Clypearia apicipennis (Spinola, 1851), Leipomeles pusilla (Ducke, 1904), Metapolybia nigra Richards, 1978, Parachartergus richardsi Willink, 1951 e Pseudopolybia langi Bequaert, 1944 pela primeira vez no estado do Amazonas e incluímos notas de distribuição.

Palavras-chave: Biogeografia; Distribuição; Parque Nacional do Jaú; Reserva Ducke.

VV Tasps (Family Vespidae) play a valuable role in agroecosystems, since they visit a large number of plants (Hermes \& KöHLER 2006; SüHS et al. 2009; SOMAVILLA \& KöHLER 2012), acting as pollinators and biological control agents of many crops (CARPENTER \& MARQUES 2001). There are six subfamilies of Vespidae in the world, three of which occur in Amazonas state, Brazil: Eumeninae, Masarinae and Polistinae; the first two subfamilies comprise solitary or primitively social wasps and the third one includes only eusocial species (CARPENTER 1993).

Brazilian Polistinae fauna is the richest in the world with 304 species, where 104 of which are endemic (op cit.). This subfamily is divided into three tribes: Mischocyttarini (Mischocyttarus, 117 species), Polistini (Polistes, 38 species) and Epiponini (19 genera and 150 species) (Noll et al. 2004; ANDENA et al. 2007a, 2007b; Noll \& Wenzel 2008; Andena et al. 2009a, 2009b; Andena \& Mateus 2011).

In the Brazilian Amazon, the pioneer works of Ducke (1904, 1905, 1907) on social wasps are regarded as the first significant studies about the biology, systematics and distribution of this group in the Eastern Amazon, especially in Pará state. So far 20 genera and 200 species of social wasps have been recorded to the Brazilian Amazon region, representing about $70 \%$ of the Brazilian Polistinae fauna (SILVEIRA 2002), which makes this biome with the greatest number of wasp species. However, there are many sample gaps in the Amazon region and distribution and occurrence studies are necessary for improving this prior knowledge. Therefore, this study aimed to contribute for the knowledge on the Amazonian social wasp fauna reporting five new occurrence records in the Amazonas state.

\section{MATERIAL AND METHODS}

Specimens of social waps were collected with entomological nets or Malaise traps during expeditions in the Ducke Reserve at the city of Manaus $\left(02^{\circ} 55^{\prime} \mathrm{S} / 059^{\circ} 58^{\prime} \mathrm{W}\right)$ and the Jaú National Park at the city of Novo Airão ( $02^{\circ} 15$ 'S/O62 ${ }^{\circ} 38^{\prime} \mathrm{W}$ ) (Figure 1 ). All specimens were deposited in the Zoological Collection of Invertebrates at the Instituto Nacional de Pesquisas da Amazônia (INPA) in Manaus. For identifications we followed the keys proposed by RichardS (1978), CARPENTER \& MARQUES (2001) and CARPENTER (2004).

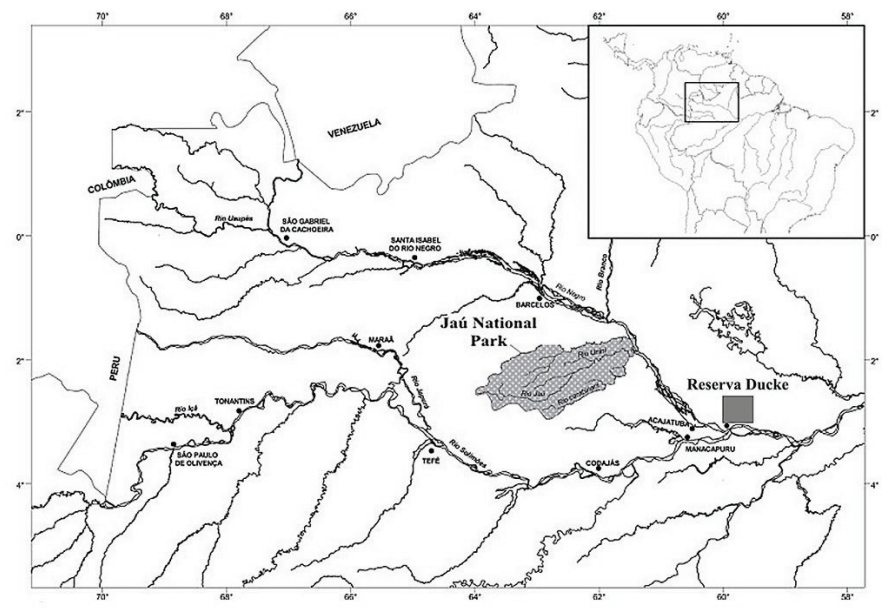

Figure 1. Localization of Jaú National Park and Ducke Reserve, Amazonas - Figure modified from Borges (2004). 


\section{RESULTS AND DISCUSSION}

Five species of Epiponini were collected for the first time in these localities, Clypearia apicipennis (Spinola, 1851) (Figure 2a), Leipomeles pusilla (Ducke, 1904) (Figure 2b), Metapolybia nigra Richards, 1978 (Figure 2c), Parachartergus richardsi Willink, 1951 (Figure 2d) and Pseudopolybia langi Bequaert, 1944 (Figure 2e).

The genera Clypearia de Saussure, Leipomeles Moebius, Metapolybia Ducke, Parachartergus R. von Ihering and Pseudopolybia Von Dalla Torre are distributed in the Neotropical region from Mexico to Argentina, and many species of these genera have been found in Brazil and in the Amazon Region (CARPENTER \& MARQUES 2001).
There are eight described species of Clypearia which is a genus distributed from Mexico to Bolivia. Seven species are recorded from Brazil and three are endemic (op cit.). Specimens of Clypearia apicipennis were collected on Ducke Reserve, Amazonas.

The genus Leipomeles has only four described species and its distribution ranges from Costa Rica to Brazil. Three species are recorded from Brazil (op cit.). Specimens of L. pusilla were collected on Ducke Reserve, Amazonas state. This species was also previously registered in Pará state.

There are sixteen described species of Metapolybia and this genus is distributed from Mexico to Paraguay. Among the seven species recorded in Brazil, only one is endemic (op cit.). Specimens of $M$.

$\mathbf{a}$
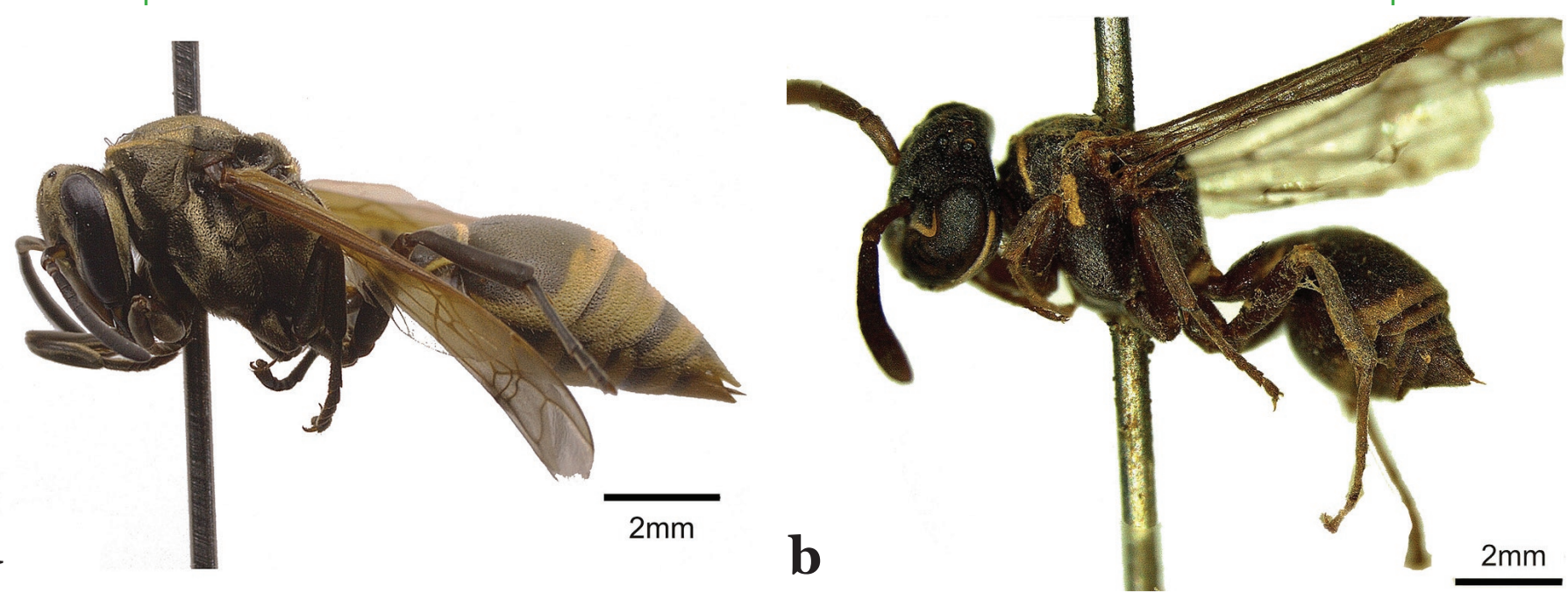

c
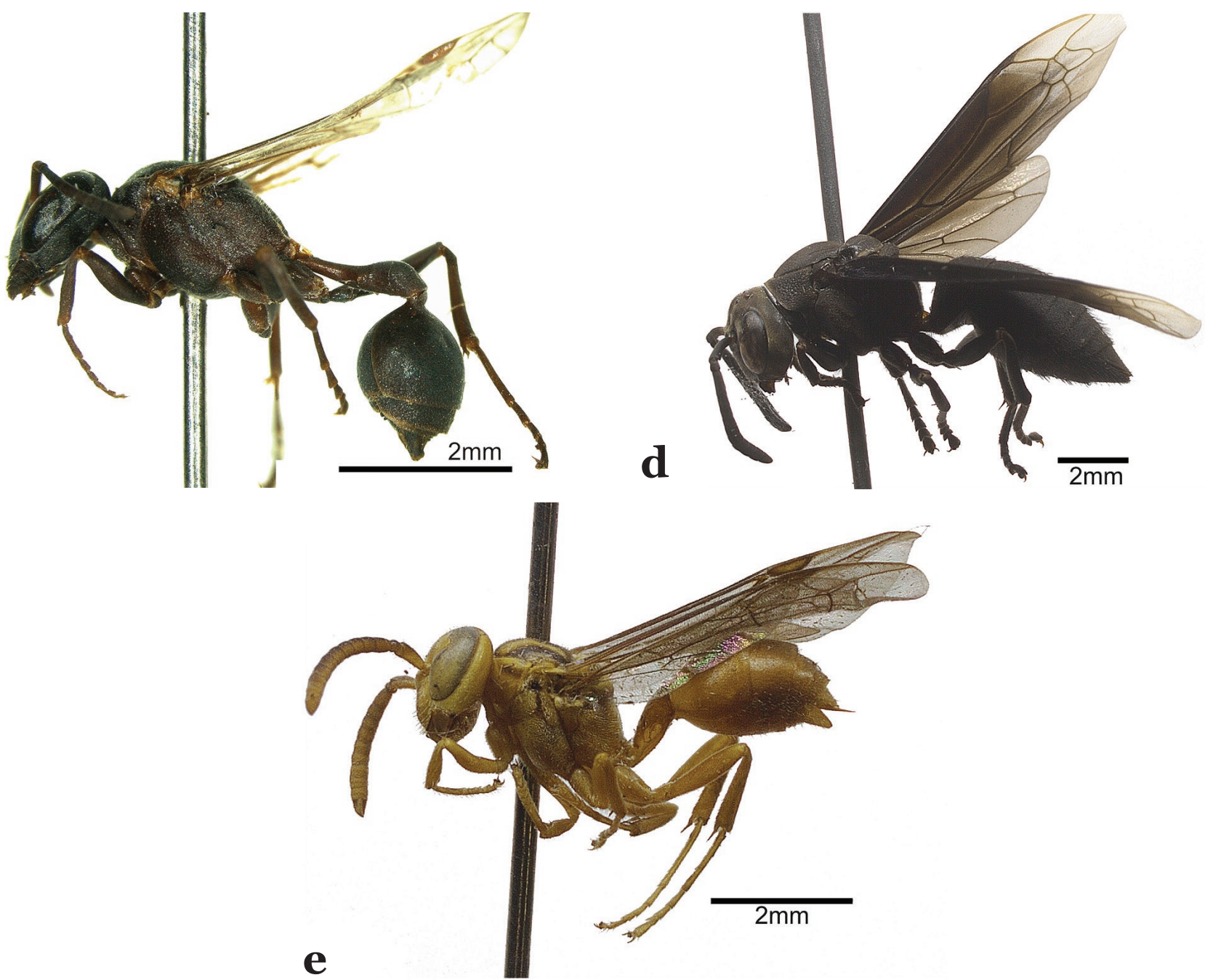

Figure 2. (a) Clypearia apicipennis; (b) Leipomeles pusilla; (c) Metapolybia nigra; (d) Parachartergus richardsi; (e) Pseudopolybia langi. Scale: 2 $\mathrm{mm}$. 
nigra were collected at the Ducke Reserve and the Jaú National Park, Amazonas state.

The genus Parachartergus has sixteen described species of and it is distributed from Mexico to Argentina. Ten species were recorded in Brazil, and only three are endemic (op cit.). Specimens of $P$. richardsi were collected on the Ducke Reserve and the Jaú National Park, Amazonas state. This species was also previously registered in Pará state.

The genus Pseudopolybia has only four species and its distribution ranges from Nicaragua to Bolivia. Three species are recorded from Brazil (op cit.). Specimens of $P$. langi were collected on the Ducke Reserve, Amazonas state. This species was previously registered in Amapá state.

This new distribution records along with the data about diversity and biology of the social wasps in the Amazonas state suggest that many species of this group has not been collected in this state yet (Silveira et al. 2008). This is especially true due to the fact that investigations were not performed in many localities (e.g. upper Solimões river near the city of Tefé; the border region with Peru and Colombia; southwest Amazonas near the Acre state Amazon region; south Amazonas near the states of Rondônia and Mato Grosso and to the east near the state of Pará). Therefore, further studies on the Amazonas state will certainly increase the knowledge of Polistinae fauna.

\section{REFERENCES}

Andena, S.R., F.B. Noll \& J.M. Carpenter, 2007a. Phylogenetic analysis of the Neotropical social wasps of the genus Angiopolybia Araujo, 1946 (Hymenoptera, Vespidae, Epiponini). Zootaxa, 1427: 57-64.

Andena, S.R., F.B. Noll, J.M. Carpenter \& R. Zucchi, 2007b. Phylogenetic analysis of the neotropical Pseudopolybia de Saussure, 1863, with description of the male genitalia of Pseudopolybia vespiceps (Hymenoptera: Vespidae, Epiponini). American Museum Novitates, 3586: 1-11.

Andena, S.R., J.M. Carpenter \& F.B. Noll, 2009a. A phylogenetic analysis of Synoeca de Saussure, 1852, a neotropical genus of social wasps (Hymenoptera: Vespidae: Epiponini). Entomologica Americana, 115: 81-89.

Andena, S.R., J.M. Carpenter \& K.M. Pickett, 2009b. Phylogenetic analysis of species of the neotropical social wasp Epipona Latreille, 1802 (Hymenoptera, Vespidae, Polistinae, Epiponini). ZooKeys, 20: 385-398.

Andena, S.R. \& S. Mateus, 2011. Description of the male of Brachygastra moebiana Saussure 1867 (Hymenoptera: Vespidae; Epiponini). EntomoBrasilis, 4: 75-77

Borges, S.H, C.C. Durigan, M.R. Pinheiro, J.L.C. Camargo \& A. Murchie, 2004. Planejando o estudo da biodiversidade na Amazônia brasileira: uma experiência no Parque Nacional do Jaú, p. 3-18. In: Borges, S.H., S. Iwanaga, C.C. Durigan \& M.R. Pinheiro (Eds.). Janelas para a biodiversidade no Parque Nacional do Jaú. Fundação Vitória Amazônica, Manaus, 273p.
Carpenter, J.M., 1993. Biogeographic patterns in Vespidae (Hymenoptera): two views of Africa and South America, p. 139-154. In: Goldblatt, P. (Ed.). Biological relationship between Africa and South America. New Halen, Yale University, 648p.

Carpenter, J.M. \& O.M. Marques, 2001. Contribuição ao Estudo dos Vespídeos do Brasil. Universidade Federal da Bahia, Departamento de Fitotecnia. Série Publicações Digitais, v. 3, CD-ROM.

Carpenter, J.M., 2004. Checklist Synonymy of the Genus Marimbonda Richards, 1978, with Leipomeles Möbius, 1856 (Hymenoptera: Vespidae; Polistinae), and a New Key to the Genera of Paper Wasps of the New World. American Museum Novitates 3465: 1-16.

Ducke, A., 1904. Sobre as Vespidas sociaes do Pará. Boletim do Museu Paraense Emílio Goeldi de História Natural e Etnografia, 4: 317-374.

Ducke, A., 1905. Nouvelles contributions à la connaissance des Vespides sociales de l'Amérique du Sud. Revue Entomological, 24: 5-24.

Ducke, A., 1907. Novas contribuições para o conhecimento das Vespas (Vespidae sociales) da Região Neotropical. Boletim do Museu Paraense Emílio Goeldi, 5: 152-199.

Hermes, M.G. \& A. Köhler, 2006. The flower-visiting social wasps (Hymenoptera, Vespidae, Polistinae) in two areas of Rio Grande do Sul state, southern Brazil. Revista Brasileira de Entomologia, 50: 268-274.

Noll, F.B., J.W. Wenzel \& R. Zucchi, 2004. Evolution of Caste in Neotropical Swarm-Founding Wasps (Hymenoptera: Vespidae; Epiponini). American Museum Novitates, 1-24.

Noll, F.B. \& J.W. Wenzel, 2008. Caste in the swarming wasps: 'queenless' societies in highly social insects. Biological Journal of the Linnean Society, 93: 509-522.

Richards, O.W., 1978. The social wasps of the Americas (excluding the Vespinae). London, British Museum of Natural History, 580 .

Silveira, O.T., 2002. Surveying Neotropical Social Wasps. An Evaluation of Methods in the "Ferreira Penna" Research Station (ECFPn), in Caxiuanã, PA, Brazil (Hymenoptera, Vespidae, Polistinae). Papéis Avulsos de Zoologia, 42: 299323.

Silveira, O.T., S.V. da Costa Neto \& O.F.M. da Silveira, 2008. Social wasps of two wetland ecosystems in Brazilian Amazonia (Hymenoptera, Vespidae, Polistinae). Acta Amazonica 38: 333-344.

Somavilla, A. \& A. Köhler, 2012. Preferência Floral de Vespas (Hymenoptera, Vespidae) no Rio Grande do Sul, Brasil. EntomoBrasilis, 5: 21-28.

Sühs, R.B., A. Somavilla, A. Köhler \& A. Putzke, 2009. Vespídeos (Hymenoptera, Vespidae) vetores de pólen de Schinus terebinthifolius Raddi (Anacardiaceae), Santa Cruz do Sul, RS, Brasil. Revista Brasileira de Biociências, 7: 138-143.

\section{Recebido em: 05/09/2012}

Aceito em: 19/o1/2013

\section{Como citar este artigo:}

Somavilla A. \& M.L. Oliveira, 2013. New Records of Social Wasps (Hymenoptera: Vespidae: Polistinae) in Amazonas State, Brazil. EntomoBrasilis, 6(2): 157-159.

Acessível em: http://www.periodico.ebras.bio.br/ojs/index.php/ebras/article/view/276. doi:10.12741/ebrasilis.v6i2.276
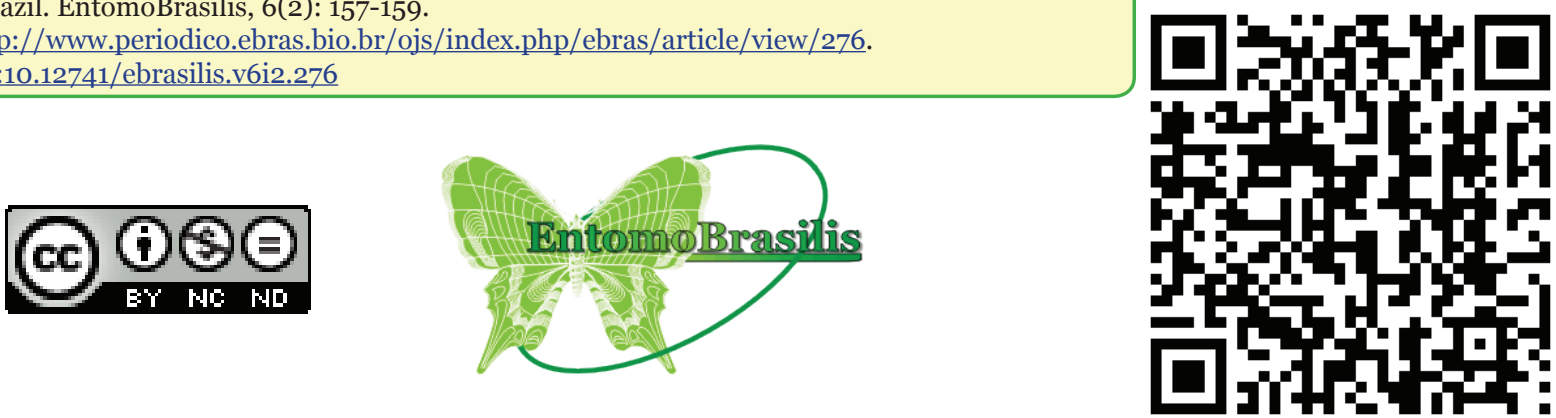